\title{
Immersion and Empathy
}

Films are lived as sensuous experiences that almost inevitably elicit emotional responses. For this reason, Béla Balázs understands the medium in terms of a heightening of the capacity for feeling, believing that every perception is infused with emotion. ${ }^{1}$ The connection between sensibility and intellect that we can already find in Balázs shall serve in this chapter as the basis for a theory of histospheres as a specific form of living (cinematic) encounter with history. My thesis is that this sort of temporally organized aesthetic encounter is what makes historical films so compelling. In this context, the first section examines the role of aesthetically modeled atmospheres and the moods they evoke. The second section builds on this examination by considering filmic space. A histosphere, I argue, creates powerful, immersive experiences based on a living encounter with filmic space, making it possible to virtually step inside the historical world constructed by the film. Filmic atmospheres and spatial figurations of movement bring us physically and mentally closer to the action of the film. At the same time, we perceive the "film's gaze" on this world-as lived by another with whom we are able to empathize. Another potent mechanism of perspectivation is film characters, and so the third section focuses on imaginative empathy with the characters who inhabit a film's historical world. In combination with film experience as a mode of embodied perception, this inner perspective provokes interpretations and evaluations that we can extend to the filmic depiction's historical references. The aim of this chapter is thus to investigate histospheres as multi-immersive

(C) The Author(s) 2021

R. Greiner, Cinematic Histospheres, https://doi.org/10.1007/978-3-030-70590-9_6 
perceptual spaces that not only model a historical world but also profoundly influence our conceptions and interpretations of history.

\section{Mood And Atmosphere}

No man's land in SKY wITHOUT STARs: Carl Altmann and Anna's son Jochen make their way through the darkness. In order to return the child to his mother's care, the border guard turns illegal border crosser. Darkness and fog obscure the characters' vision. Next to the abandoned railway station stands the carcass of a freight car. The frame is segmented by trees and wooden fences, and rhythmized by rapid shot-reverse shot montages. A combination of filmic signifiers and conventions signals danger (Figs. 6.1, $6.2,6.3$, and 6.4 ).

It is not just the visual information that evokes a vague air of menace, but also the dark tonal sequences of the score. The atmosphere permeates everything. Like a "nebulous primal matter" or "aroma," it envelops all

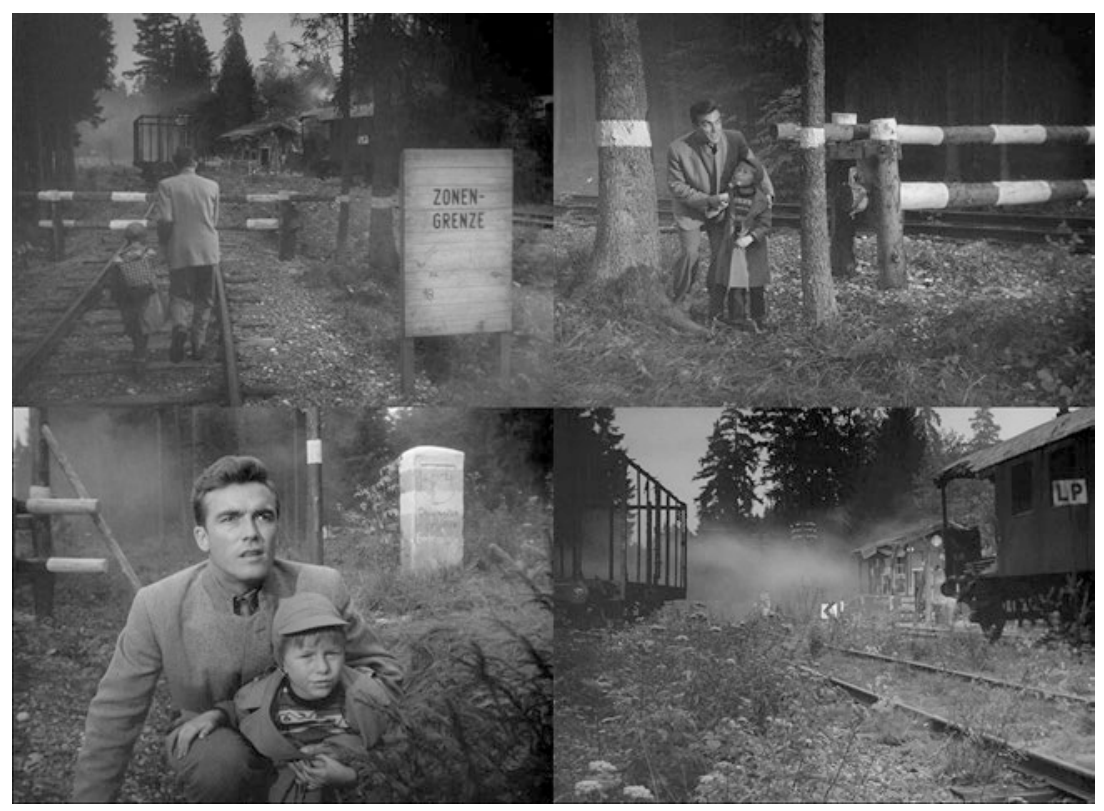

Figs. 6.1-6.4 Menacing atmosphere in SKY without STARS 
the histosphere's forms and structures. ${ }^{2}$ Balázs describes the notion of an "anthropomorphous world" as follows:

Every shape makes a-mostly unconscious-emotional impression on us, which may be pleasant or unpleasant, alarming or reassuring, because it reminds us, however distantly, of some human face, which we ourselves project into it. Our anthropomorphous world-vision makes us see a human physiognomy in every phenomenon. ${ }^{3}$

What Baláz is saying here, phrased somewhat dramatically, is that cinematic atmospheres are constructions capable of eliciting emotional responses from us. In Ricœurian terms, atmosphere should therefore be understood as part of the filmic world's "configuration," whereas a mood is only generated by a process of "refiguration" in interaction with the spectator. ${ }^{4}$ Moreover, as holistic experiences, moods cannot be reduced to their individual elements. Or, in the words of Margrit Tröhler, "mood and atmosphere do not issue from the individual object, but from constellations of objects, and thus describe overall qualities." ${ }^{5}$ One such constellation of objects is formed by a film's aesthetic-figurative aspects, which in the case of historical films are also augmented by imaginary historical referents. In an associative network of "memories, thoughts, habits, physiological reactions, and vocalizations," $"$ a histosphere's atmosphere can evoke complexly interrelated emotions and moods ${ }^{7}$ of varying magnitudes. As long ago as 1920, Danish director Urban Gad in his book Der Film distinguished between the mood [Stimmung] that can be produced by certain stylistic devices within a shot and the basic/general mood [Grundstimmung] of a film as a whole. ${ }^{8}$ Though they do not directly reference Gad, Hermann Kappelhoff and Jan-Hendrik Bakels build on this idea in their concept of the "spectator feeling":

The spectator feeling is neither an individual unit of affect nor an aggregation of discrete emotions; rather, it is connected to continuous modelings of a complex emotion (a mood, an atmosphere) that unfolds over the course of a film and is founded in aesthetic pleasure. ${ }^{9}$

Consequently, even when historical films depict painful periods of history, such as the division of Germany in SKY WITHOUT STARS, the spectator feeling is not wholly negative, but rather ambivalent in nature. The aesthetic pleasure that accompanies the audiovisual modeling of a historical world serves 
an entertainment function and is generally regarded positively. The "temporal organization of the living aesthetic encounter with the film" thus forms "the ground, the matrix of the spectator feeling." 10 As constituents of this feeling, atmospheres do not just comment on and shape the depiction of the historical world, but make painful history bearable and thus available to experience. The spectator feeling has a similar function to Siegfried Kracauer's example of the shield of Athena, which Perseus uses in the Greek myth in order to battle Medusa without looking at her directly. ${ }^{11}$ However, the pleasure we take in historical films and the unique attraction of histospheres are based not in the ontology of film images but on the temporally organized living aesthetic encounter with a film and the mood associated with it.

The distinction between atmosphere and mood is based on an epistemological difference that should not be discounted: While the associative living encounter with filmic atmospheres evokes subjective moods in the spectator, the atmospheres themselves are based on the "general expressive repertoire of cultures" and are thus also "relatively stable at an intersubjective level." 12 Media scholar Hans J. Wulff goes so far as to claim that filmic atmospheres "ultimately belong to the semiotic sphere." ${ }^{13}$ In a histosphere, atmospheres are thus not merely part of the configuration of the film's historical world, but can also be described in the epistemological terms of semiotics. The illegal border crossing in SKY WITHOUT STARS is assigned to a sphere of secret and forbidden things by cultural codes such as darkness, the forest, and mist, while cinematic conventions such as the fragmented image composition and rapid shot-reverse shot montages create a menacing scenario. However, as Tröhler puts it, "a minimal distance" is needed to decode the signifiers and "become aware of the atmosphere, the mood, the aura in a situation." 14

The use of spatial categories that can be observed in Tröhler's argument suggests that atmosphere and filmic space are interwoven. The neophenomenologist philosopher Hermann Schmitz defines feelings as "spatially, but placelessly, poured-out atmospheres," as illustrated by examples such as an ominous "calm before the storm" or the proverbial "air so thick you could cut it with a knife." ${ }^{15}$ According to Schmitz, these atmospheres have the potential to "physically affect" a subject in a way that goes beyond mere perception. ${ }^{16} \mathrm{He}$ further argues that the totality of feelings forms a "feeling space" with a structure similar to his notion of bodily space (der leibliche Raum). ${ }^{17}$ Film atmospheres are likewise constituted regardless of whether spectators engage with them emotionally. If 
they do, however, then atmosphere does not just allow the spectator to observe and perceive an emotional mood, but also affects them physically. This dual structure of atmosphere and mood can once again be linked to Vivian Sobchack's phenomenology of film experience. ${ }^{18}$ Perceiving a film as a world of pictures and sound and simultaneously as an intentional, embodied perspective on this world gives rise to an experience of reception that alternates between mere cognitive understanding and physically palpable sensation. A histosphere's atmospheres can, accordingly, be understood as semiotically coded readings of the depicted historical worlds and events. They can also allow the moods they produce to be physically experienced. It can be assumed that the associated conceptions of history and intuitive judgments on the part of spectators are highly dependent on the construction of a film's atmospheric dimension.

In an interview, director Fred van der Kooij remarked that filmmakers have at their disposal all the elements needed to create and control an atmosphere, ${ }^{19}$ in particular weather conditions and parameters of spatial design such as lighting, color, sizes, and proportions. His list focuses primarily on film images, and needs to be supplemented with elements of sound design too. Ambience in particular plays a key role in constructing filmic spaces and giving them a distinctive impression of reality. ${ }^{20}$ Composed of diverse sounds and tones, ambience brings the film image to life and evokes a continuous cinematic world that extends far beyond the boundaries of the frame. In a histosphere, ambience creates an atmospheric impression of a bygone world, for instance through sounds of historic road traffic. The interaction between sound and image creates a holistic overall impression and generates synesthetic added value. ${ }^{21}$ Following Schmitz, the resultant intermodal sensory qualities can be understood as "bodily [leibnahe] bridging qualities" that mediate between atmospheres and corporal-emotional affectedness. ${ }^{22}$ Another way that film can use sound to create a certain atmosphere is through its construction of a space's acoustic qualities. As well as establishing the size of a space by means such as muffled sounds, resonance, or echoes, sound can also convey an impression of a space's material properties. ${ }^{23}$ Walking on marble sounds different from walking on a carpet. The sound a material makes is also closely tied to its haptic qualities: A room with a marble floor will tend to feel colder and sleeker than one with a soft, warm carpet. These synesthetic perceptions likewise function as "bodily bridging qualities." ${ }^{4}$ This corporal-emotional effect of atmosphere enables us to physically experience the historical spaces constructed by film. As described by Frank 
R. Ankersmit in his work on historical experience, this can evoke the feeling of direct contact with history. ${ }^{25}$ At the same time, we constantly compare the synesthetic perception of historical spaces' atmospheres with the corresponding imaginary historical referents. Our expectations also depend on a space's function: A train station or airport can be permeated with a melancholy atmosphere of departure, but they can also promise freedom and arouse curiosity about the big wide world. ${ }^{26}$ If such a place is deprived of its function, this affects its atmosphere too. The abandoned train station in SKY WITHOUT STARS exudes an eerie atmosphere during the night-time border crossing, and this atmosphere also has a historical dimension. The disused platforms and ruined building are filmically constructed traces of the past that attest to the consequences of German division. The physically lived mood produces a cognitive resonance. By being emotionally exposed to the historical world simulated by the film and evaluating the feelings it evokes, we take a stance toward the imaginary historical referent, which will inevitably also affect our conceptions and interpretations of history.

Filmic space also has a historiographical, narrative component. When van der Kooij asks what history the objects in a space have for the spectators, his question concerns the "refiguration" 27 of the historical world. Our personal experiences and memories blend with the perception and experience of the audiovisually configured historical world. Van der Kooij's hypothesis that knowledge of what has previously happened in a space helps determine its atmosphere is of central importance for historical films. The filmic figuration of historical spaces is geared precisely toward this effect. ${ }^{28}$ If we know what has previously happened in a space, it will be infused with a corresponding atmosphere and we will start to anticipate what might happen there next. The historical space of the inner German border constructed by SKY WITHOUT STARS, for instance, presupposes knowledge about the many people who were killed attempting to cross the border illegally. This results in a menacing atmosphere, which is further intensified by audiovisual metaphors of death and transience, such as the "carcass" of the freight car. This conception of atmospheres is congruent with Martin Seel's “atmospheric appearing”:

In the form that they have, the objects of this appearing give the respective situation a characteristic form, in such a way that this character of the situation-a character co-created by them-becomes intuitable in these objects. ${ }^{29}$ 
A histosphere integrates objects with a specific associative potential, in particular ones that connect to the spectator's media-generated "prosthetic memories." ${ }^{30}$ As a media signifier of history in the spectator's memory, the wreckage of the freight car is not just a general cinematic symbol of transience and death, but also makes reference to the deportation trains of the Third Reich, one of the most common metaphors for the Holocaust's machinery of death. Seel's definition of "atmospheric appearing" formulates a key aspect of histospheres: "While perceiving, we look into how it is, or how it was, or how it could be to exist here and now, or to have existed there and then." ${ }^{31}$ Filmic atmospheres help connect histospheres to different levels of the historical past. They give the world constructed by the film its own historicity, which in atmospheric appearing also draws on the spectators' associatively evoked memories and emotions.

Film characters are also part of the audiovisually constructed historical spaces and atmospheres. Moreover, the historical world constructed by a film shapes their physiology, psychology, and actions. On Seel's understanding, atmosphere is "a sensuously and affectionally perceptible (and, in this respect, existentially significant) articulation of realized or nonrealized life possibilities" 32 that are manifested in and through the experience of the historical world constructed by film. ${ }^{33}$ On Wulff's view, meanwhile, atmospheres are "emotional qualities" that are "deliberately designed to affectively draw audiences into perceiving an object a certain way" and follow their own dramaturgy. ${ }^{34}$ When Carl Altmann and little Jochen reach the small East German town of Broditz in SKY wITHOUT STARS, the scene initially picks up the menacing atmosphere of the previous sequence: In a low-angle close-up, we see a grim-looking Russian soldier with a machine gun. The frame only opens up after the camera tracks back for a few moments and pans to the "House of Friendship," the meeting place of the FDJ (East Germany's youth organization), which is decorated with portraits of Communist politicians Wilhelm Pieck and Walter Ulbricht. From off-screen, we hear folksy violin and piano music, and the bustle of a busy square. People out on a stroll, a busy cafe, string lights, and a candy stall create a warm, pleasant atmosphere: The scenery is now far more evenly lit, and unsettling shot-reverse shot montages have been replaced with sedate sequence shots (Figs. 6.5, 6.6, 6.7, and 6.8).

The audiovisual design models a relaxed atmosphere that prompts a reevaluation of the air of menace associated with East Germany until this point. Although atmosphere primarily serves to accentuate the emotional and somatic experience of certain moods, in historical films it also 


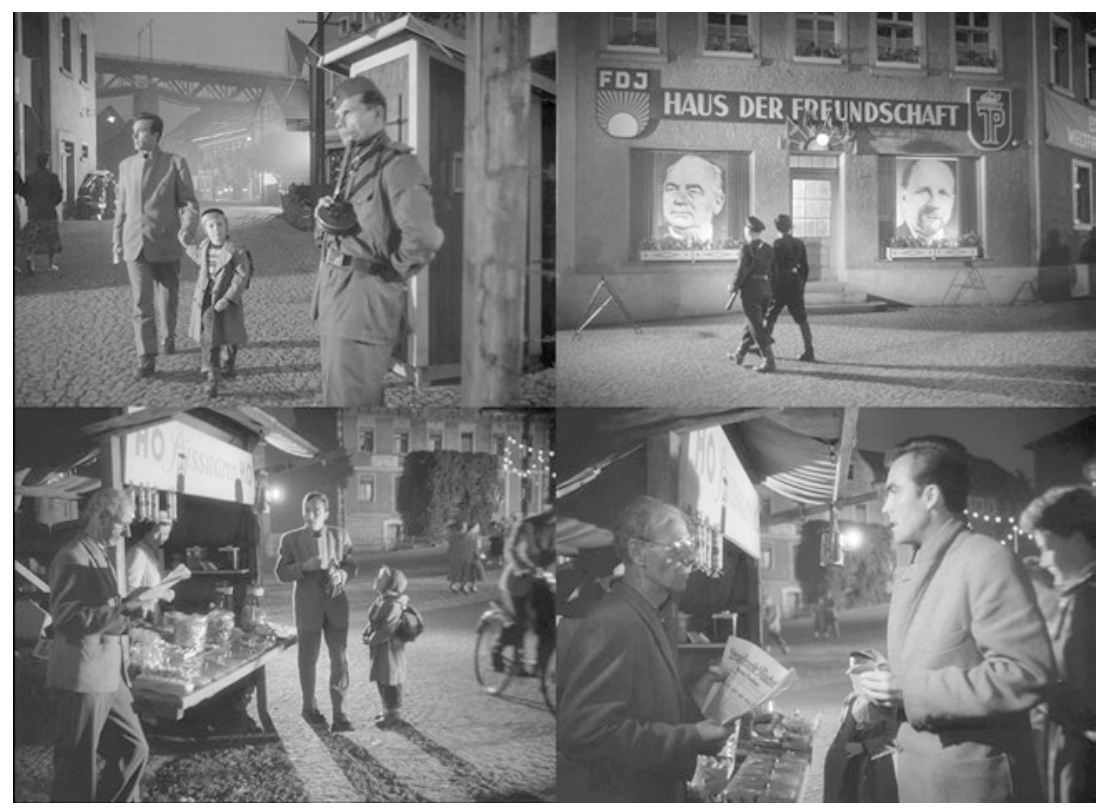

Figs. 6.5-6.8 Change in atmosphere in SKY WITHOUT STARS

contributes to the narrativization of history. The dramaturgy of atmosphere has the potential to steer and direct our perceptions of the historical world constructed by the film at an affective and emotional level, and thus also the conceptions and interpretations of history we derive from it.

Another way in which an aesthetic experience of historicity can be created is through the use of historical film technology and audiovisual conventions. Old-style camera lenses and sound recording methods have their own distinctive aesthetic that helps give a film a historical atmosphere. So too does the choice of film stock: Factors such as photosensitivity, contrast, and granularity leave a specific impression that spectators can intuitively situate within history. The same applies to the colors: Black and white or sepia tones can signify media historicity, while historical color processes such as Technicolor can be dated to particular periods of film history. Jörg Schweinitz observes that "for extended periods (until major technical changes occur once again)" film stock and its technical parameters possess "a distinctive quality that is inscribed into films and has a significant effect on their atmosphere," ${ }^{35}$ and that while contemporary 
audiences generally process this distinctive quality automatically, in retrospect the historical film stock appears far more artificial. ${ }^{36}$ The atmosphere evoked by the film stock's appearance points directly to the historicity of what is perceived:

The experience of being able to cast a photographic and hence relatively transparent gaze at the world (of the past) oscillates with the historical material filter that permeates the whole atmosphere simultaneously becoming increasingly palpable. ${ }^{37}$

Atmospheres evocative of historical films can shape histospheres in various ways. For instance, the black and white footage, slightly crackling sound, and traditional score of Helmut Käutner's SKY WITHOUT STARs lend it the character of a historical document. This effect is reinforced by the fact that the film was made just three years after the time it is set. In Jutta Brückner's YEARS OF HUNGER, meanwhile, historical archive footage from the 1950s is spliced into fictional sequences. The camera's observing stance, the electronic music, the main character's way of speaking, and various other details, however, represent aesthetic strategies of New German Cinema. As a result, the fictional sequences have a markedly different atmosphere than the grainy, flickering, and scratched archive footage (Figs. 6.9 and 6.10). This abrupt shift in atmosphere draws attention to the nearly thirty-year gap between the different layers of the film's historicity, thereby opening up space for reflection. The opposite effect is achieved by the slight decoloration of the images in Sven Bohse's KU'DAMM

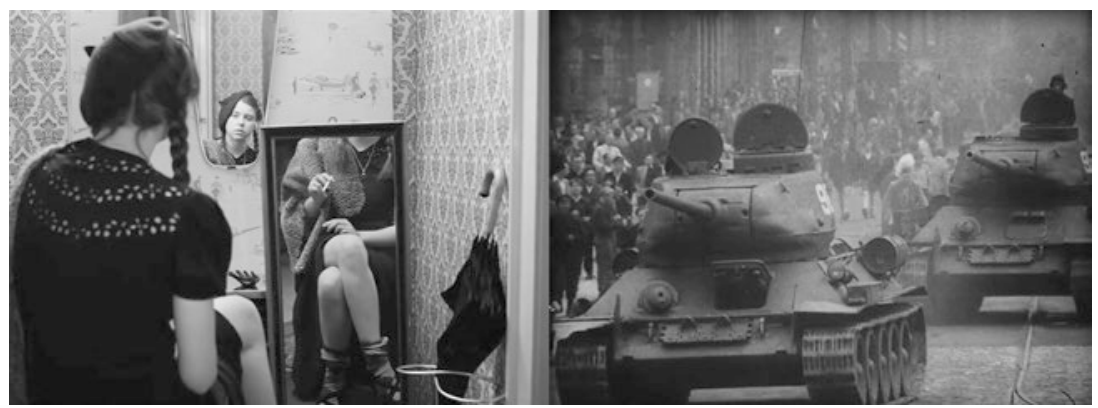

Figs. 6.9-6.10 Differing material qualities: aesthetics of New German Cinema and archive footage in YEARS OF HUNGER 
56 , inspired by the aesthetic of faded photographs from the period being depicted. Thus, while a filmic space's audiovisually formed atmosphere shapes perception of the historical world constructed by the film and associatively links it to spectators' subjective recollections and media-generated "prosthetic memories," atmospheres evocative of film history add another layer to histospheres that marks out the film itself as a historical document.

\section{IMMERSIVE EXPERIENCES}

Over the sound of rousing beats, a host in a glittery jacket calls contestants in "Berlin's first rock 'n' roll championships" to the dance floor. Glaring spotlights illuminate the well-filled, slightly smoky hall. The camera pans across the cheering audience. A young woman, Monika Schöllack, runs toward us, and we follow her with a crane shot. After a series of rapid cuts, the competition begins. The audience goes wild when the first guitar riffs sound. Monika takes a runup, jumps, and is propelled into the air by Freddy. Transcendent music plays. Monika soars through the air in slow motion (Fig. 6.11).

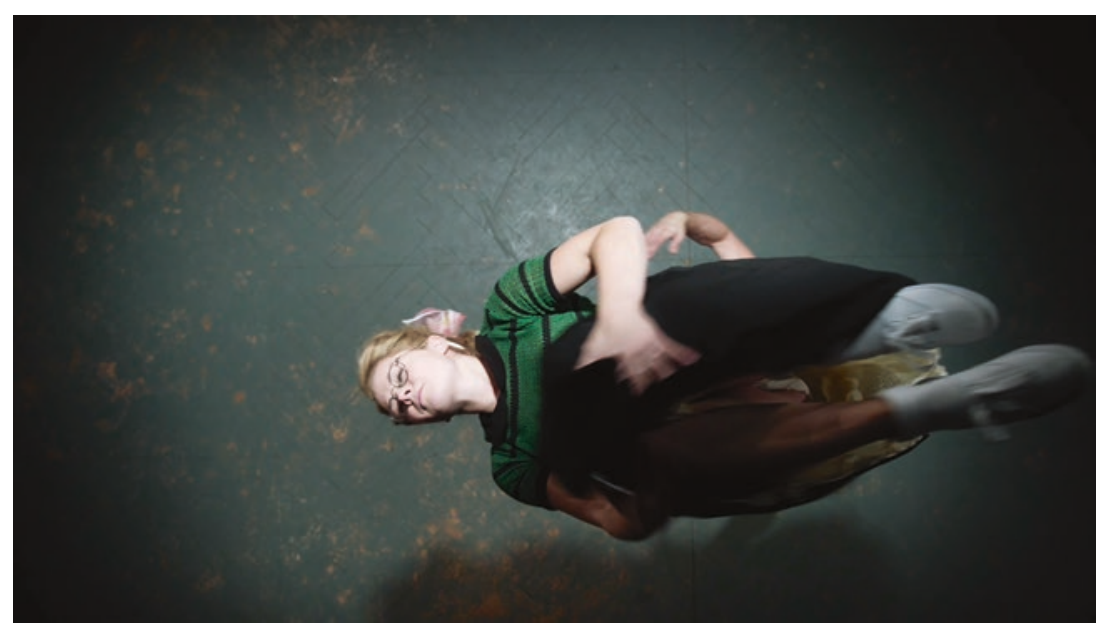

Fig. 6.11 The moving camera in KU'DAMм 56 
The moving camera takes my eye, and so also my consciousness, along with it: into the image, into the scene of the action. I see nothing from the outside. I see everything just as the actors in the scene must. I am surrounded by the forms of the film and thus enmeshed in its action. I walk with the characters, drive with them, fall with them-even though physically I remain sitting in the same place. ${ }^{38}$

Balázs's euphoric description anticipates the modern concept of "fictional immersion": Under the influence of moving audiovisual stimuli, a large part of the spectators' attention is "drawn away from their environment and directed wholly to the artifact." 39 They are, as it were, "submerged" in a "stream of moving images." 40 It is not just film images' captivating illusion of movement that contributes to the immersive effect, but also film sound. Whirls of sound and physically palpable bass tones, like the heartbeat-like sound effect used during Monika's somersault at the start of KU'DAMM 56, involve us more strongly in the action of a film at a somatic level. The illusion of movement, the film's use of sound, and the emotional effect of the atmosphere create a "bodily bridging quality." ${ }^{41}$ In this way, a histosphere's audiovisual figurations construct a historical world that enfolds us and brings us physically and mentally closer to the action of the film. ${ }^{42}$ My thesis is that in historical films this closeness helps the historical past seem less distant too. To explore this thesis in more depth, in this section I shall examine various theories of immersion and look at whether they are compatible with a theory and praxis of histospheres. I combine psychoanalytic concepts with theories of space and the body. My exploration culminates in a multi-immersive model that understands immersion as a constitutive element of the living cinematic encounter with history.

Immersive film experiences are generally classed as the result "of a rapid movement through space" and thus as a function of perception. ${ }^{43}$ In these experiences, we feel as though we are being physically transported into the filmic world. However, simply describing the "movie ride aesthetic" 4 underlying such experiences is insufficient for an analysis of cinematic immersion as a component of a histosphere; the immersive potential of empathy also needs to be taken into account.$^{45}$ Immersion not only transports us into the historical world constructed by a historical film, but also enables us to sensuously experience and $f e e l$ it. The living aesthetic encounter transcends the limits of naturalistic strategies of representation. ${ }^{46}$ Empathy extends not just to characters but also to "inanimate objects such 
as colors, shapes, moods, and spaces." ${ }^{47}$ Balázs concurs: "In the film [... man and background are of the same stuff, both are mere pictures and hence there is no difference in the reality of man and object." 48 In the dance sequence at the start of KU'DAMM 56, we are immersively absorbed not just by the thrilling figurations of movement but by the aesthetically composed atmosphere. The glaring spotlights, whose light is refracted in the haze of the pulsating dance hall, the beat of the music, the shapes and colors of the gaudy shirts and whirling skirts - all these things draw us into the spell of the histosphere (Fig. 6.12). The petticoats and the vintage cars parked on the edges of the dance floor serve as iconic symbols of the 1950s, supplementing the mise-en-scène with a mise-en-histoire. ${ }^{49}$ Our empathetic engagement with the objects, sensations, and moods of the filmic figurations is augmented by associatively recalled historical references; together, they blend into a dreamlike illusion. ${ }^{50}$

To describe this phenomenon more precisely, I shall draw on Christian Metz's psychoanalytic work on cinema and dream. Metz believes that true illusion can only exist in dreams ${ }^{51}$ while in cinema we can always discern a certain "impression of reality." ${ }^{2}$ For Metz, immersive film experience has more in common with daydreams:

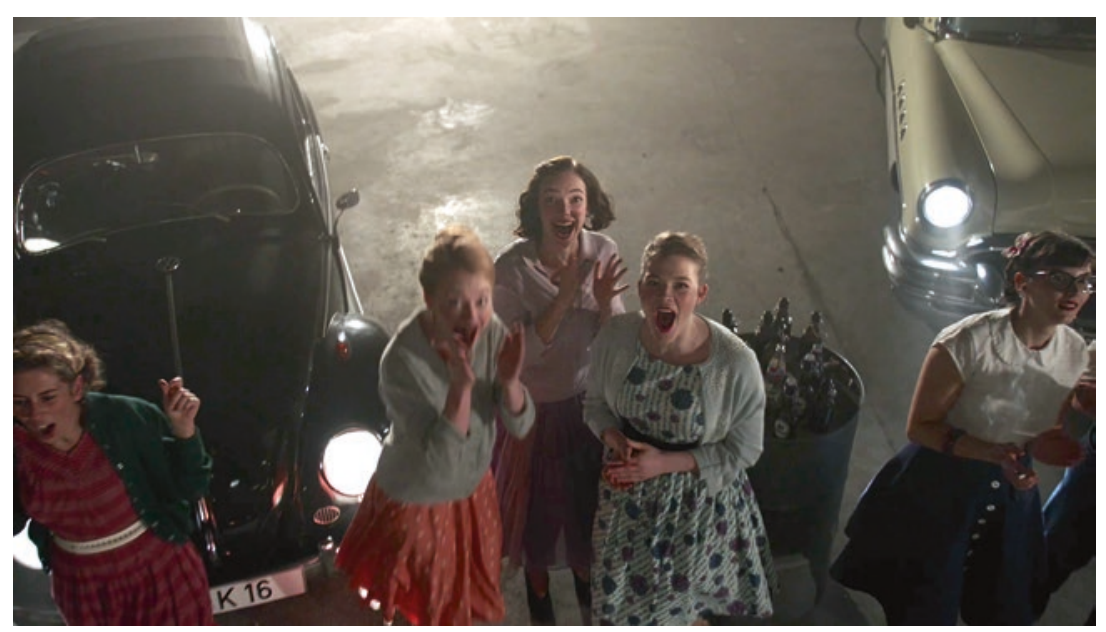

Fig. 6.12 Iconic symbols of the 1950s in KU'DAMм 56 
Just as the spectator knows that he is watching a film, the daydream knows that it is a daydream. Regression is exhausted in both cases before reaching the perceptual agency; the subject does not confuse the images with perceptions, but clearly maintains their status as images: mental representations in the daydream, and in the film representation of a fictional world through real perceptions. ${ }^{53}$

On this view, while watching a historical film we remain certain that the film's historical world is merely an artificial construction, a function of filmic figuration. ${ }^{54}$ This certainty - and this is Metz's second thesis-can, however, be overridden in moments of exceptionally intense affective involvement by a temporary state of "paradoxical hallucination" akin to the "brief and quickly passing dizziness that drivers feel towards the end of a long night journey. ${ }^{55}$ Metz considers film to be one such journey:

In the two situations, when $[\ldots]$ the brief psychical giddiness $[\ldots]$ ends, the subject not coincidentally has the feeling of "waking up": this is because he has furtively engaged in the state of sleeping and dreaming. The spectator thus will have dreamt a little bit of the film: not because that bit was missing and he imagined it: it actually appeared in the bande, and this, not something else, is what the subject saw; but he saw it while dreaming. ${ }^{56}$

Via a detour through the realm of dream, the filmic figuration becomes a form of hallucinatory perception. Marie-Laure Ryan's concept of immersion builds on this idea. During reception of a film, the filmic world forms a new frame of reference for the spectator that brings about a recentering: "We are theoretically, emotionally, and mentally transported into a fictional world as soon as the presented objects, beings, and relations create for us their own tangible reference space. ${ }^{" 57}$ Although this reference space is experienced as a product of dreamlike imagination, it "is not reducible to an internal psychical process," 58 but is based on a real sensory perception:

The spectator receives images and sounds offered as the representation of something other than themselves, of a diegetic universe, but remaining true images and sounds capable of reaching other spectators as well, whereas the dream flux can reach the consciousness of no one but the dreamer. ${ }^{59}$

Historical films add another element to the mix. The images and sounds of a histosphere do not just represent a diegetic universe, but through the mise-en-histoire are also linked to the imaginary historical referents in our 
memory. The historicity derived from remembered associations is projected onto the film's material figurations, which can in turn be sensuously experienced. This interweaving of emotional and cognitive processes with a film's synesthetic affects actually appears to facilitate the "slide" into a state of dreamlike hallucination. The source of the immersive effect thus lies in the interplay between sensory perception and meaning-making reflection, or as Sobchack puts it:

When we sit in a movie theater and perceive a film as sensible, as making sense, we (and the film before us) are immersed in a world and in an activity of visual being. The experience is as familiar as it is intense, and it is marked by the way in which significance and the act of signifying are directly felt, sensuously available to the viewer. ${ }^{60}$

Sobchack's idea that the immersively intensified perception of filmic figurations makes both significance and the act of signifying sensuously available to the spectator can also be applied to histospheres. We immersively perceive not just the historical world constructed and configured by a film, but also its genesis in a process of refiguration and historical referentialization. The filmic illusions of movement in the dance sequence at the start of KU'DAMM 56-the movement of bodies and camera, the montage, the beat of the music - are, on the one hand, direct, immersive stimuli as described in the notion of the "movie ride aesthetic." On the other hand, they also construct specific impressions that in the process of perception coalesce with the film design elements of the mise-en-sceine to form an imaginary picture of a historical world, which is referentialized by the mise-en-histoire.

But what if "films do not offer any worlds or comprehensive worldviews, and in terms of their perceptible location within a space-time continuum only ever remain disconnected fragments"? In that case, according to Christiane Voss, the concept of immersion would serve

as the metaphorical linchpin of a utopian promise that has perhaps always been associated with the medium of film: the promise of being able to experience a living and meaningful temporality beyond the bounded horizons of one's own finitude. ${ }^{61}$

For Voss, filmic immersion makes plot into a "temporarily focused matrix" of the spectators' perception. ${ }^{62}$ On this premise, the spectators' 
multi-immersive engagement refigures the film's audiovisual figurations into an "imaginary index" ${ }^{33}$ and links this index to the histosphere's imaginary historical referents, so that the world of the histosphere is experienced as an "ephemeral reality." 64 Perceptions drawing on this multi-immersively generated "imaginary index" bring about a (temporary, imaginary, and necessarily incomplete) recentering of the spectator. The unconscious reassurance that one is physically present in the movie theater is temporarily overridden, though without disappearing completely. As part of a histosphere, the immersive potential of filmic figurations makes us feel as if we are partially leaving behind the place from which we are watching the film, whether that be a movie theater seat or our living room couch, and embarking on a "journey" to a historical world. The key to this phenomenon lies in the construction and experience of the filmic space.

As an audiovisual figuration, space is constituted in the medium of film "out of an affective moment of being-in-the-world, that is to say, out of the specific experience [Erleben] of space that a film enables for the spectator." ${ }^{65}$ At the same time, the spectator "is so strongly addressed in their bodyliness by the film [...] that they involuntarily respond to the parameters of this space-whether with nausea or kinetic excitement."66 Space functions as a "cognitive and phenomenological interface between the spectator and the world of the film," while the "lived body" represents the prereflective interface between filmic space and reception space. ${ }^{67}$ Consequently, understanding this dimension of filmic immersion once again requires a combination of perceptual and phenomenological theories. Voss augments Sobchack's notion of the "cinesthetic subject" ${ }^{8}$ with an emphatically spatial dimension: "In their intellectual and sensoryaffective response to the action of the film," the spectator adds to the twodimensional film image the "third dimension of their feeling body" and thus becomes "a constitutive element of the film's architecture." ${ }^{69}$ By contrast with Sobchack, for whom the film's body surrounds that of the spectator while the spectator in turn incorporates the film's perception, ${ }^{70}$ for Voss the film's "borrowed body" is "truly a space-a somatic space of meaning" that creates the third dimension "in which the action of the film can be sensuously and affectively embedded." 71 The immersive dimension of the borrowed body's spatialization consists in spectators' regarding "that which we somatically (co-)constitute and at the same time experience [erleben] as being directly truthful in this form." ${ }^{72}$ Voss's model offers a plausible explanation for the intense impression of a histosphere's bringing history to life. The contiguity of historical world and subjective 
perception evokes the feeling of being able to physically touch the past, which closely parallels Frank R. Ankersmit's definition of historical experience, ${ }^{73}$ in which the impression of coming into direct contact with the past is accompanied by a "disappearance of temporal dimensions." ${ }^{74}$ The film's complex temporal structure overrides the spectator's perceptions of the time in which they are actually watching the film, such that "the borrowed body's response" follows "the fictional passage of time in the constructed film narrative." 75 This strengthens the "living entanglement with the action of the film" ${ }^{76}$ while freeing us as spectators from the linear temporal logic of our everyday perception. For instance, the dance sequence at the start of KU'DAMM 56 does not just represent a leap forward in time; the slow motion shot of Monika's somersault also emphatically alters our perception of time. Immersion thereby embeds both the spatial and temporal structures of the filmic figurations in the borrowed body's somatic space of meaning, allowing us to experience historical worlds through experiencing ourselves.

\section{IMAGINATIVE EMPATHY}

Lost in thought, a young woman stares into space as she peels potatoes, while the score broadens out into transcendent tones. In this scene in KU'DAMM 56, the shallow depth of field and the cut from a long shot to a close-up isolate Monika from her surroundings (Figs. 6.13 and 6.14). Hyperrealistically modulated noises and the protagonist's despondent sob lead into a flashback to a painful memory.

"Films articulate a subjective experience of the world [Welterleben] that the spectator realizes as a sensation in their own body [körperliches Empfindungserleben] and also as a particular way of perceiving the world,"77 as Hermann Kappelhoff and Sarah Greifenstein write. The world configured out of images and sounds is not perceived "in the schemas of our everyday perception of the world, but in the mode of a distinct, unfamiliar experience [Erleben] by another entity." ${ }^{78}$ If, however, film experience is "the expression of experience by experience," then this requires the capacity for empathy and makes it a relevant parameter for a theory of histospheres. We do not merely live the historical world of the film as a sensuous experience; rather, at the same time we perceive the film's perspective on this world-as lived by another with whom we are able to empathize ${ }^{80}$ On the basis of immersion, affect, and empathy, we construct and live a "culturally encoded [...] form of temporal existence." ${ }^{81}$ In this 


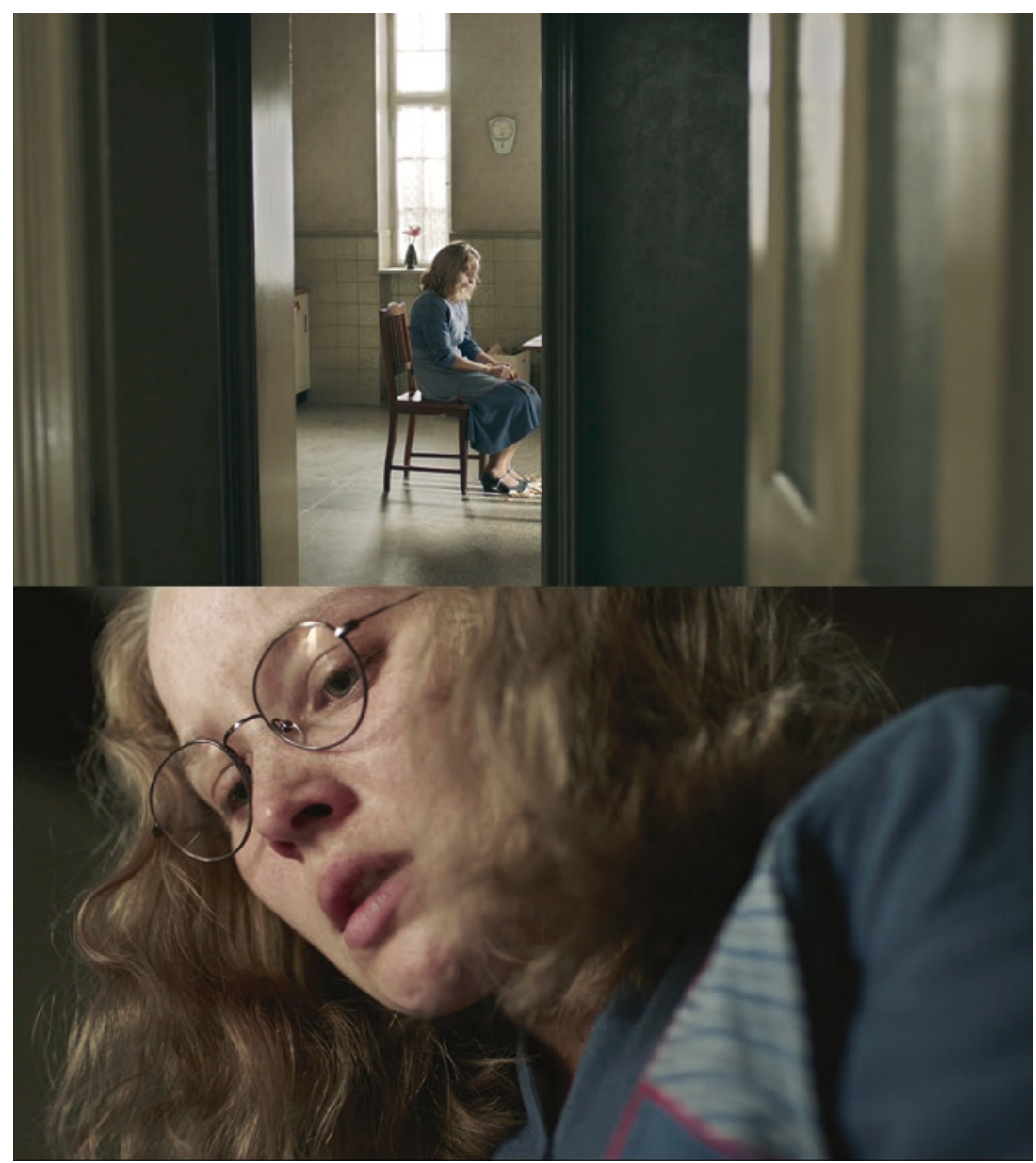

Figs. 6.13 and 6.14 Aesthetics of memory in КU'DAMм 56

process, we often enter into an intimate imaginary relationship with the film character, especially if that character's perception coincides with the film's subjective experience of the world. We see Monika in the filmic world while simultaneously gaining an impression of her perception of this world. Facial expressions and gestures, close-ups, a slight slow motion effect, and the hyperrealistically amplified noises help foster empathy. This 
phenomenon was described early in the history of film theory by Balázs, whose observation that the camera causes us to "identify" with the characters in a film not just spatially but also emotionally ${ }^{82}$ anticipates the essential features of "imaginative empathy." ${ }^{83}$ Audiovisual design allows us to "imagine what it is like to experience what happens in the fiction film." 84 In a detail shot, we see Monika trudging through long grass and hear the sound of tweeting birds, rustling leaves, and rumbling thunder. When it starts to rain, she takes a deep breath and begins to relax. The long, drawnout notes of the score blend with piano tones into an emphatically soaring melody. Monika takes off her wet clothing and begins to dance as if in a trance. The film's gaze is largely congruent with the character's implied perception of the world. Panning and tracking shots, the rhythmic elliptical montage, and brief slow motion effects imitate the rapt movements of the dancing body (Figs. 6.15 and 6.16).

The film's audiovisual operations make it easier for us to empathize with another person's way of perceiving the world. The imaginative activity combines with our actual sensory impressions into a distinctive experience. ${ }^{85}$ However, this does not mean "that spectators must always notice acts of $[\ldots]$ imagining" as such. ${ }^{86}$ Instead, we can observe a close connection to immersion: Imaginative empathy "throws" us into the thick of the action. In an immersive process, we enter into the audiovisually configured filmic world. Our emotional responses may mirror those of the characters. But, as described by phenomenological approaches to film, we may also "emote to the events of the film as if [we] had really been witnessing them," sympathizing with the character from an external perspective but without coming "to feel the same way as the character does." 87 The philosopher Amy Coplan has coined the term "experiential understanding" 88 for the process of simultaneously sharing in the observed experience of another person and taking their perspective, while also reflecting on that experience from the outside. The dual structure of seeing and being seen underlying this concept was once again anticipated by Balázs:

A film frame shows us not just what this spectator sees but how he sees it. This how is a characteristic feature, that is, a feature of artistic design. This how characterizes not just the object, but also the spectator: his "view" of the object and its relation to him. Every view of the world gives rise to a worldview. Every camera perspective expresses an inner perspective. ${ }^{89}$ 


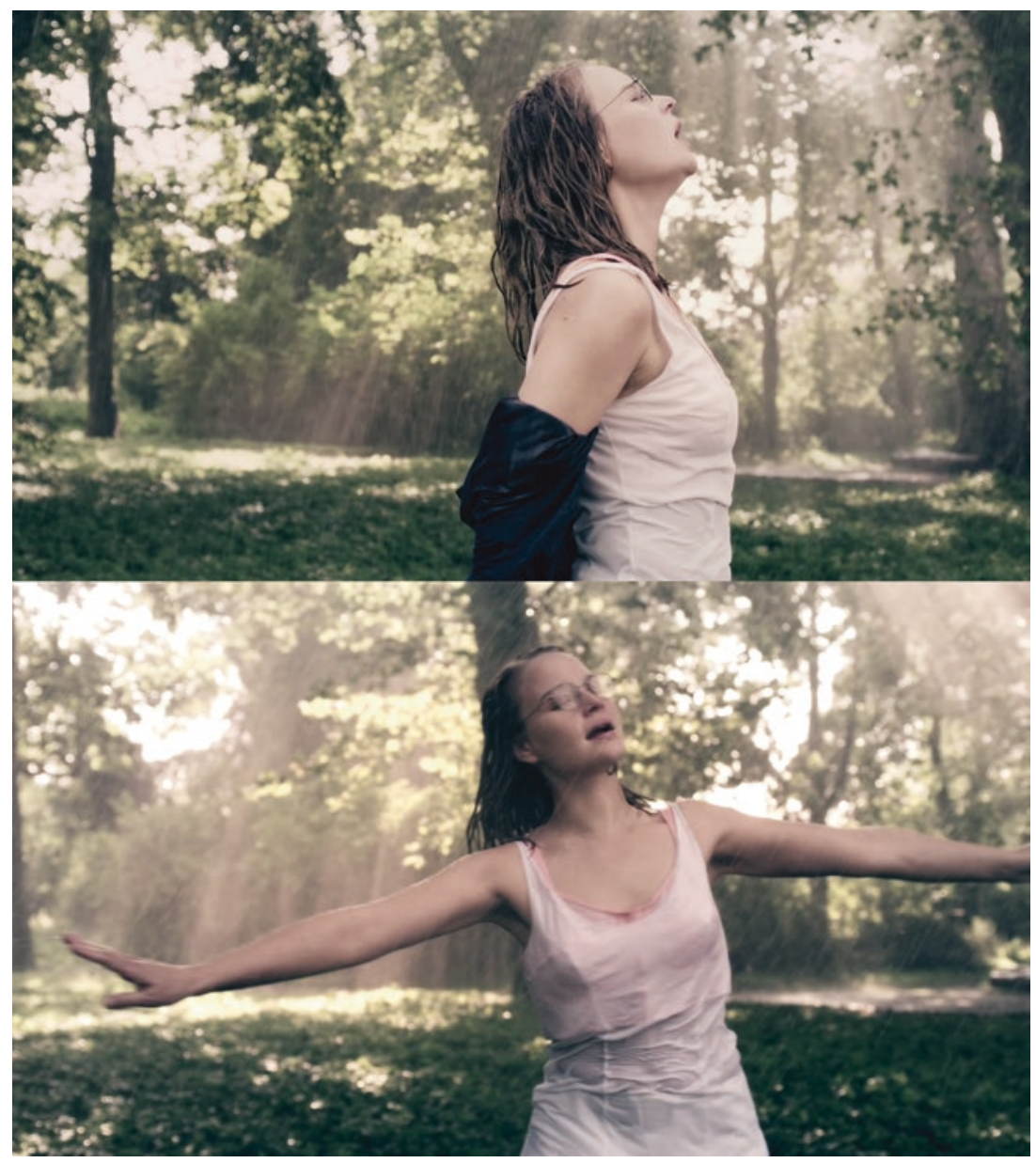

Figs. 6.15 and 6.16 Imaginative empathy: Monika's dance in КU'DAмм 56

Balázs draws a connection between aesthetic and ideological perspectivation-a process also mirrored in the above-described sequence from KU'DAMM 56: In the "how" of viewing and simultaneously being-viewed, we experience Monika's yearning for freedom in our own body, we feel her inner drive to escape the constricting, outdated norms of the 1950s. Imaginative empathy has the potential to "direct and control" our feelings 
to some degree, allowing them to be harnessed for very different communicative purposes. ${ }^{90}$ For instance, sensuous emotional empathy in combination with historical referentialization can allow spectators to experience historical ideologies. Although in historical films imaginative empathy therefore has the potential to model historical perspectives, we are not forced to accept these perspectives. ${ }^{91}$

Empathy can sometimes manifest itself in a sequence's "specific aesthetic form." 92 The potential of audiovisual form to strengthen our capacity for empathy can also be seen in Monika's dance in KU'DAMM 56: The caressing movements of the camera, the elliptical montage, the soaring music, the whooshing sound effects, and the hyperreal sound of the protagonist's breathing create an immersive effect that heightens empathetic involvement. Aesthetic experience can even trigger a form of empathetic engagement that detaches itself from the specific film character and allows the experiences imparted by the film to be "appreciated for their sensuous pleasures alone." 93 Whether it is the exuberant illusion of movement or a detail like sunrays refracted in the rain, the empathetically felt aesthetic experience during Monika's dance also gives the histosphere an aesthetic quality that can be interpreted retrospectively-under the influence of the reflexively operating mise-en-histoire-as a historical feeling (Fig. 6.17). Thus, as spectators we continuously alternate between different modes of

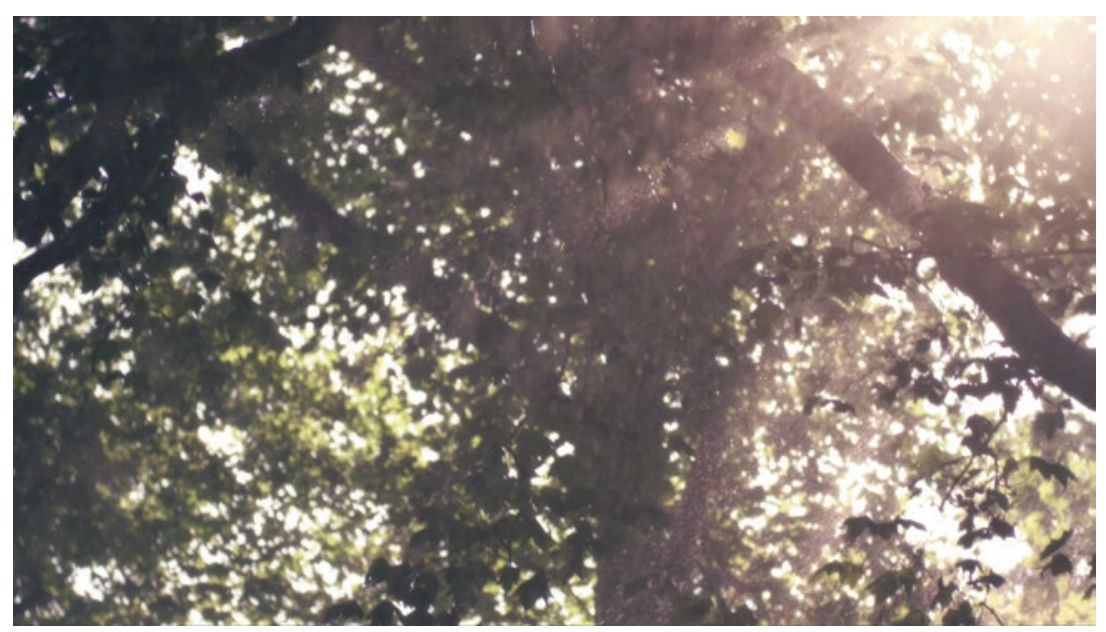

Fig. 6.17 Aesthetic experience in KU'DAMм 56 
perception "in order to explore the film both fictionally and aesthetically." 94 Aesthetic experience, imaginative empathy, and historical experience thus fuse into a unified living encounter that combines both cognitive and corporal aspects.

The very idea that we can empathize with historical figures initially seems paradoxical. If we assume that the capacity for empathy is inversely proportional to the temporal, geographic, and cultural distance between the world of the film and the world of our own lived experience, ${ }^{95}$ this capacity would be greatly impeded in historical films. But the great success of historical films makes this conclusion improbable. Instead, empathy must be supplemented by a dose of acentral imagining. Similarly to the model proposed by Sobchack, the spectator assumes a dual position from which "they both participate in the action and are confronted by it." 96 The "inferences and typifications" $" 97$ undertaken in this process are facilitated by genre conventions such as the use of stereotypical character attributes; empathizing with a character in a historical world constructed by a film involves interpreting that character "as a social or sociopsychological type in their milieu." 98 We have the impression of being able to immerse ourselves in the film's historical world in a mode of living encounter. Empathy allows us not just to discern a character's emotional state but also to reflect on these emotions. ${ }^{99}$ Combining this character with other characters allows us to construct a "social field": ${ }^{100}$ As Wulff writes, "a character with whom perhaps we 'primarily' empathize is juxtaposed with a matrix of other, 'secondary' characters with whom we must also empathize." The "reciprocal perceptions and interpretations of the characters among themselves"101 mark fictional film as a "construction of a fictional world of social action." 102 The historical experiences generated by historical films are based on the historical social system constructed by a film and the spectator's living, empathetic encounter with that system. History is represented in terms of human relations. ${ }^{103}$ In KU'DAMM 56, Monika's spontaneous dance in the rain is watched by a group of walkers. Most of them are young men who seem to be enjoying the spectacle, but their leader, a smartly dressed and much older man, looks appalled (Fig. 6.18). Our empathy with the characters gives us a sense of being able to relive the inhibited society of 1950s West Germany from the inside. Empathy also contributes to forming a particular picture of history.

In summary, the phenomenological concept of empathy involves not just "imaginatively adopting a perspective" but also "a bodily [...] resonance." 104 Kracauer spoke of "kinesthetic responses" to moving visual 


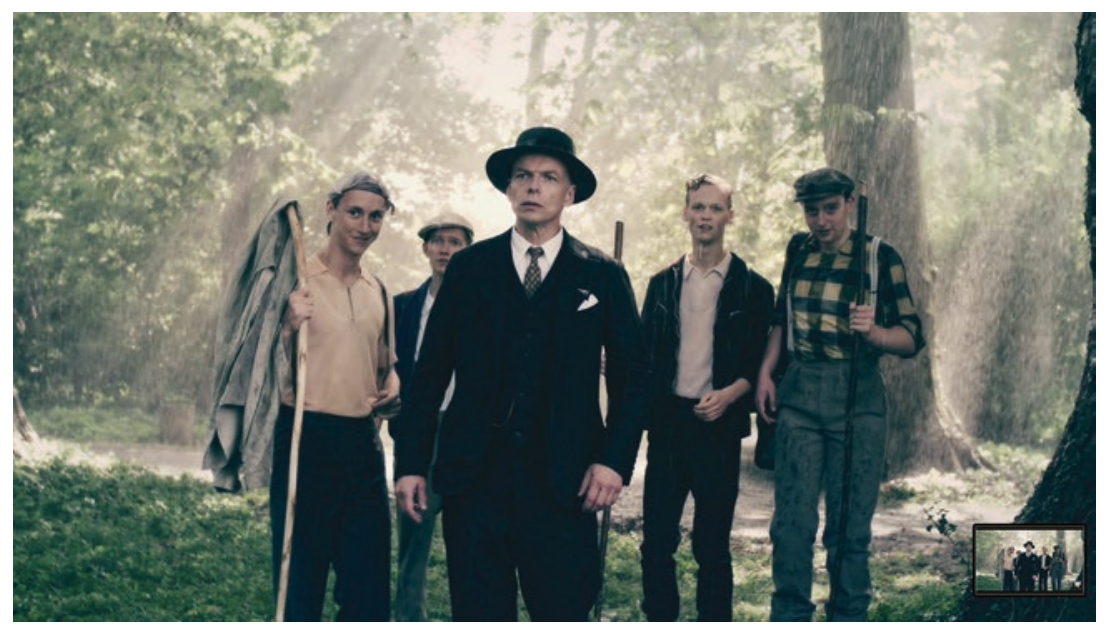

Fig. 6.18 Empathy and "social field" in KU'DAMm 56

stimuli $^{105}$; more recent research has sought to link such ideas to scientific studies of physical motor resonance. Neurological experiments have shown that certain neurons in primates' brains exhibit the same pattern of activity both when watching and when performing an action. ${ }^{106}$ Since both visual and aural indications of certain actions can trigger sensorimotor resonance, ${ }^{107}$ this would seem to be a role the audiovisual medium of film is especially well suited to play. Although Kappelhoff's criticism that these sorts of psychological models operate with an empiricism wholly alien to the discipline of film studies is valid, ${ }^{108}$ there is no denying that as spectators we can be physically affected by moving stimuli in film, such as during Monika's dance in KU'DAMM 56. However, it is not "simply the observed movements, but specific (sensori)motor acts" that trigger a response. ${ }^{109}$ Monika's movements follow a certain pattern; they are part of a structured, expressive dance. The philosopher Hartmut Rosa believes that complex actions, situations, and sense-references of this kind can be grasped or mirrored not just by way of sensorimotor equivalents, "but above all by evoking and shaping narrative connections." 110 Sensorimotor resonance is integrated into a narrative matrix that facilitates imaginative empathy. This means that it is only through telling stories that we become able to adopt complex experiential perspectives. ${ }^{111}$ Narrative also allows us to empathetically make moods and atmospheres present to ourselves and 
imaginatively corporally apprehend them. ${ }^{112}$ For instance, black and white pictures do not just make reference to something old and historical, but also have their own expressive quality, an atmosphere, which represents a certain perspective. ${ }^{113}$ The philosopher Susanne Schmetkamp connects the thesis of narrative modeling of experiential perspectives to phenomenological theories:

On this account, empathy involves a process of perceiving a person's specific state, their feelings, and their actions, in particular the way in which they are manifested in bodily expression and from that person's specific perspective. This entails that perspective-taking is not just cognitive but also corporal, inasmuch as it is also always perspectives of bodies, objects, and moods that are made present. ${ }^{114}$

This approach is of interest for a theory of histospheres for two reasons. Firstly, the process of making-present implies a historicity that is already inscribed in the medium of film, consonant with Kracauer's and Benjamin's theories. ${ }^{115}$ Secondly, the above-described process expresses a crucial shift in the triadic relation between subject, film, and history. While the "phenomenal undertone of feeling" creates a resonance "between the spectator's body and the film's body," at a cognitive level there remains an I-You divide that makes the empathizing person aware "that it is not they themselves who has these feelings." 116 In imaginative projection, the spectator wonders "how he himself would have reacted emotionally and how he would have behaved, had he himself been experiencing the events in the film." 117 This combination of imaginative and acentral empathy represents a crucial point of difference from scholarly historical writing. The "objectification and projection of ourselves-now as others-then" is replaced in the historical film by "subjectification and projection of ourselves-now as wethen."18 The tension between imaginative empathy and cognition can "make the spectator reflect on relevance for himself." 119 This self-reflection extends beyond the horizons of the fictional world and gives historical films the potential to substantially influence our conceptions of history.

\section{CONCLUSION}

In this chapter, I analyzed historical films as multi-immersive perceptual spaces, and concluded that histospheres can exert an especially profound influence on our conceptions and interpretations of history if they allow 
spectators to physically "live" the filmically modeled historical worlds. This temporally organized aesthetic encounter not only forms the basis for the great popularity of the historical film genre, but also (as a condition for producing an audiovisual history) has a significance that goes far beyond the medium of film.

A particular role is played in this process by audiovisually constructed atmospheres, which allow histospheres to evoke moods and emotions. My investigation showed that the corporal-emotional effect of atmosphere enables us to physically experience the historical spaces constructed by film. Filmic atmospheres evoke a feeling of direct contact with history, ${ }^{120}$ our conception of which is augmented by associatively evoked memories and moods. These include media-generated "prosthetic memories." By being emotionally and physically exposed to the history simulated by the film and reflecting on the feelings it evokes, we take a stance toward the imaginary historical referents of the mise-en-histoire. The dramaturgy of atmosphere has the potential to steer and direct our perceptions of the historical world constructed by the film at an affective and emotional level, and thus also the conceptions and interpretations of history we derive from it. I also observed that atmospheres evocative of film history add another layer of meaning to histospheres that marks out the film itself as a historical document.

To provide a theoretical underpinning for my arguments, I examined various theories of immersion and considered whether they are compatible with a theory and praxis of histospheres. Historical films construct atmospheric worlds that enfold us and bring us physically and mentally closer to the action of the film. My thesis is that in historical films this closeness helps the historical past seem less distant, too. Christian Metz's psychoanalytic approach shows how filmic figurations can, via a detour through the realm of dream, be transformed into hallucinatory perceptions. My analysis shows that these ideas can also be applied to the theoretical concept of histospheres. Our empathetic engagement with the sensations and moods of historical films is augmented by associatively recalled historical references; together, they blend into a dreamlike illusion. The historicity derived from remembered associations is projected onto the film's material figurations, which can in turn be sensuously experienced. This interweaving of emotional and cognitive processes with synesthetic affects facilitates the "slide" into a state of dreamlike hallucination. As part of a histosphere, the immersive potential of filmic figurations makes us feel as if we are leaving behind the place from which we are watching the film, 
whether that be a movie theater seat or our living room couch, and embarking on a "journey" to a historical world. The key to this phenomenon lies in the construction and experience of the filmic space. Christiane Voss's model of a "borrowed body" - a "somatic space of meaning" in which "the action of the film can be sensuously and affectively embedded"-offers a plausible explanation for the intense impression of a histosphere's bringing history to life. ${ }^{121}$ A film's complex temporal structure overrides the spectator's perceptions of the time in which they are actually watching the film and strengthens the "living entanglement with the action of the film," 122 while freeing us as spectators from the linear temporal logic of our everyday perception. On this view, we do not enter into the historical film's historical worlds; rather, they enter into us. Thus understood, filmic immersion plays a key part in allowing histospheres to make us feel as though we are physically experiencing the past-through experiencing ourselves.

Atmosphere, mood, and immersion are closely interwoven with concepts of imaginative empathy, which must likewise be considered relevant to a theory of histospheres. On the one hand, empathy allows us to grasp the emotional states of film characters. We can then in turn relate these characters to other characters and to ourselves, resulting in an empathetically experienceable model of a historical social system. Sensuous emotional empathy in combination with historical referentialization can thereby allow spectators to experience historical ideologies. According to Vivian Sobchack, we do not merely live the historical world of the film as our own, subjective experience; rather, at the same time we perceive the film's perspective on this world-as lived by another with whom we are able to empathize. On the basis of immersion, affect, and empathy, we have the impression of being able to immerse ourselves in the film's historical worlds in a mode of living encounter. The empathetically felt aesthetic experience gives the histosphere a quality that can be interpreted retrospectively - under the influence of the reflexively operating mise-enhistoire - as a historical feeling. This also allows us to empathetically make moods and atmospheres present to ourselves and imaginatively corporally apprehend them. ${ }^{123}$ My theory of histospheres proved especially compatible with Susanne Schmetkamp's model of empathy, which is based on an embodied process of making-present and perspective-taking. Particular emphasis is given, first, to the implicit power of film to make the past present; and second, to the crucial shift away from academic historiography. The "objectification and projection of ourselves-now as others-then" is 
replaced in the historical film by "subjectification and projection of ourselves-now as we-then." 124 The dynamic relation between imaginative empathy and cognition that histospheres can engender extends beyond the horizons of the fictional world and has the potential to influence our conceptions of history in general: Dimensions of cinematic expression such as mood and atmosphere, in conjunction with processes that produce immersion and empathy, enable imaginative experiences of history with enormous power.

\section{Notes}

1. See on this point Matthias Hein, Zu einer Theorie des Erlebens bei Béla Balázs, Würzburg 2011, p. 21.

2. Béla Balázs, Visible Man, in Béla Balázs: Early Film Theory, New York and Oxford 2010, p. 22.

3. Béla Balázs, Theory of the Film: Character and Growth of a New Art, Scotts Valley 2015, p. 92.

4. For the definition of Ricœur's terms "configuration" and "refiguration," see Paul Ricœur, Time and Narrative, vol. 1, Chicago and London 1984a, pp. 53-54, 64-70; and the section on "Figuration and illusion" in the previous chapter of this present volume.

5. Margrit Tröhler, "Filmische Atmosphären - Eine Annäherung," in Philipp Brunner, Jörg Schweinitz, and Margrit Tröhler (eds.), Filmische Atmosphären, Marburg 2012, pp. 13-14. Tröhler also refers here to Gernot Böhme, who locates atmosphere in the relation "between" subject and object, and often speaks in this connection of "impressions" [Anmutungen] that affect us emotionally. See Gernot Böhme, Anmutungen: Über das Atmosphärische, Stuttgart 1998, p. 8.

6. Hermann Kappelhoff and Jan-Hendrik Bakels, "Das Zuschauergefühl Möglichkeiten qualitativer Medienanalyse," ZfM 5, 2011, p. 83.

7. According to Greg M. Smith's "mood cue approach" (as paraphrased by Kappelhoff and Bakels (2011, p. 83)), "continuously, repeatedly feeling a certain emotion results in the formation of a mood coherent with that emotion"; conversely, "mood-as an emotional disposition-subsequently facilitates coherent emotional responses." See Greg M. Smith, Film Structure and the Emotion System, Cambridge 2007, p. 41.

8. Urban Gad, Der Film: Seine Mittel, seine Ziele, Berlin 1920, pp. 76, 105. See on this point also Daniel Wiegand, who further clarifies this distinction by coining the terms Bildstimmung (picture mood) and filmische Gesamtstimmung (overall mood of a film). Daniel Wiegand, "Die Wahrheit aber ist es nicht allein': Zur Idee der Stimmung im Film nach 1910," in Brunner et al. (2012, p. 197). 
9. Kappelhoff and Bakels (2011, p. 86).

10. Ibid.

11. Siegfried Kracauer, Theory of Film: The Redemption of Physical Reality, Princeton 1997, p. 305.

12. Hans J. Wulff, "Prologema zu einer Theorie des Atmosphärischen im Film," in Brunner et al. (2012, p. 119).

13. Ibid.

14. Tröhler (2012, p. 11).

15. Hermann Schmitz, "Gefühle als Atmosphären und das affektive Betroffensein von ihnen," in Hinrich Fink-Eitel and Georg Lohmann (eds.), Zur Philosophie der Gefüble, Frankfurt 1993, p. 23.

16. Ibid., p. 26. On this point, Robert Gugutzer writes: "On a neophenomenological view, grief [Traner] is a feeling, that is to say, an atmosphere, which becomes the physical sensation of sadness [Traurigkeit] when a person is palpably affected by the atmosphere." Robert Gugutzer, "Hermann Schmitz: Der Gefühlsraum," in Konstanze Senge (ed.), Hauptwerke der Emotionssoziologie, Wiesbaden 2013, p. 306.

17. Hermann Schmitz, Der Leib, der Raum und die Gefüble, Bielefeld and Locarno 2007, pp. 47-57.

18. Vivian Sobchack, The Address of the Eye: A Phenomenology of Film Experience, Princeton 1992, p. 56.

19. Fred van der Kooij in ATMOSPHäre: UNTERSUCHUNGEN ZU EINEM BEgrifF (2010; dir. Elisabeth Blum).

20. On ambience, see reference 76 in the previous chapter of this present volume.

21. As already discussed in the chapter "Audiovisual history" (in the section "History as audiovision"), Michel Chion coined the term valeur ajouté to describe the "added value" generated by the interaction between film image and film sound. Michel Chion, Audio-Vision: Sound on Screen, New York 2019, p. 202.

22. Although Schmitz's examples do not explicitly refer to film, the mechanisms he discusses could certainly be reproduced by cinematic devices. See Hermann Schmitz, "Über das Machen von Atmosphären," in Anna Blume, Zur Phänomenologie der ästhetischen Erfahrung, Freiburg and Munich 2005, p. 38.

23. Barbara Flückiger, Sound Design: Die virtuelle Klangwelt des Films, Marburg 2012, p. 331.

24. Schmitz (2005, p. 38).

25. Frank R. Ankersmit, Die historische Erfahrung, Berlin 2012, p. 19.

26. See also Mikhail Bakhtin's concept of the chronotope (as discussed in the previous chapter). Mikhail Bakhtin, "Forms of Time and of the Chronotope in the Novel," in his The Dialogic Imagination: Four Essays, Austin 1981. 
27. Ricœur (1984a, p. 82).

28. This is in a certain sense a spatial variation on the moment in Marcel Proust's In Search of Lost Time (1913-1927) when the taste of a madeleine dissolved in tea vividly reawakens memories of childhood.

29. One example Seel gives is of a ball that "reminds us of the sound of children who are long gone." Martin Seel, Aesthetics of Appearing, Stanford 2005 , p. 92.

30. By "prosthetic memory," Alison Landsberg is referring to media representations of history that are subsequently recalled as if they were events we had experienced ourselves. See Alison Landsberg, Prosthetic Memory: The Transformation of American Remembrance in the Age of Mass Culture, New York 2004, p. 2. I go into this aspect of histospheres in more detail in the section "Prosthetic postmemory" in the next chapter.

31. Seel $(2005$, p. 94$)$.

32. Ibid., p. 92.

33. My argument is based here on an understanding of "art as experience," which according to John Dewey (as paraphrased by Kappelhoff and Bakels, who develop the category of "spectator feeling" on the basis of Dewey's theory) consists in "the conscious experience [Erleben] of the undivided unity of a continuous process of emotional modulation unfolding over time." Kappelhoff and Bakels (2011, p. 80).

34. Wulff $(2012$, p. 110).

35. Jörg Schweinitz, "Von Transparenz und Intransparenz: Über die Atmosphäre historischen Filmmaterials," in Brunner et al. (2012, p. 46).

36. Schweinitz speaks of a "peculiar defamiliarization." Ibid., p. 47.

37. Ibid., p. 48.

38. Béla Balázs, "Zur Kunstphilosophie des Films," in Franz-Josef Albersmeier (ed.), Texte zur Theorie des Films, Stuttgart 1998, p. 212.

39. Christiane Voss, "Fiktionale Immersion," in Gertrud Koch and Christiane Voss, "Es ist, als ob": Fiktionalität in Philosophie, Film- und Medienwissenschaft, Munich 2009, p. 126.

40. Anke Zechner, Die Sinne im Kino: Eine Theorie der Filmwahrnehmung, Frankfurt 2013, p. 49.

41. Schmitz (2005, p. 36).

42. Conversely, Balázs also speaks of eliminating the "spectator's position of fixed distance: a distance that hitherto has been an essential feature of the visual arts." Béla Balázs, The Spirit of Film, in Béla Balázs: Early Film Theory, New York and Oxford 2010, p. 99.

43. Robin Curtis and Christiane Voss, "Fielding und die movie-ride-Ästhetik: Vom Realismus zur Kinesis," montage AV 17:2, 2008, p. 11.

44. Ibid.

45. See Robin Curtis, "Immersion und Einfühlung: Zwischen Repräsentationalität und Materialität bewegter Bilder," montage $A V$ 17:2, 2008, p. 97. 
46. Ibid.

47. See Theodor Lipps, Leitfaden der Psychologie, Leipzig 1906, p. 196. Above, I have cited the paraphrase of Lipps's theory by Curtis, who persuasively applies them to film. Curtis $(2008$, p. 99$)$.

48. Balázs concludes that film, like painting, "offers the possibility of giving the background, the surroundings, a physiognomy no less intense than the faces of the characters-or, as in Van Gogh's late pictures, an even more intense physiognomy, so that the violent expressive power of the objects makes that of the human characters pale into insignificance." Balázs $(2015$, p. 96).

49. On the concept of mise-en-histoire, see the section "From mise-en-scène to mise-en-histoire" in the previous chapter.

50. On the concept of illusion, see the section "Figuration and illusion" in the previous chapter.

51. Christian Metz, The Imaginary Signifier: Psychoanalysis and the Cinema, Bloomington and Indianapolis 1982, p. 107.

52. Ibid.

53. Ibid., p. 133.

54. Gertrud Koch speaks of "awareness of illusion." See Koch (2016, pp. 51-52).

55. Metz (1982, pp. 103-104).

56. Ibid., p. 103.

57. See Marie-Laure Ryan, Narrative as Virtual Reality: Immersion and Interactivity in Literature and Electronic Media, Baltimore and London 2001. Here, I have quoted Voss's summary of Ryan's theory. Christiane Voss, Der Leihkörper: Erkenntnis und Ästhetik der Illusion, Paderborn 2013 , p. 183.

58. Metz (1982, p. 109).

59. Ibid.

60. Sobchack (1992, p. 8).

61. Voss $(2009$, p. 138).

62. Christiane Voss, "Fiktionale Immersion," montage AV 17:2, 2008, p. 82.

63. Ibid., p. 83.

64. Voss notes that "narrative anticipations and flashbacks, intertextual references, and emotional and moral identifications with a film's characters and viewpoints" feed into "our immersive experiences just as much as physical and affective responses to the material, aesthetic qualities of cinematic means of representation." Voss (2009, pp. 135-138).

65. Oliver Schmidt, Hybride Räume: Filmwelten im Hollywood-Kino der Jahrtausendwende, Marburg 2013, p. 107.

66. Curtis $(2008$, p. 95).

67. Schmidt (2013, p. 90). 
68. According to Sobchack, the cinesthetic subject simultaneously experiences themselves as a detached observer of the film's audiovisual figurations and as a synesthetically involved participant in the filmic world: "We both perceive a world within the immediate experience of an 'other' and without it, as immediate experience by an 'other.'” Sobchack (1992, p. 10). See also Vivian Sobchack, Carnal Thoughts: Embodiment and Moving Image Culture, Berkeley 2004, pp. 53-84.

69. Christiane Voss, "Filmerfahrung und Illusionsbildung: Der Zuschauer als Leihkörper des Films," in Gertrud Koch and Christiane Voss (eds.), ... kraft der Illusion, Munich 2006, p. 81.

70. “The film's body materially surrounds us as other human bodies never can after we leave the womb." Sobchack (1992, p. 222).

71. Voss $(2006$, p. 81$)$.

72. Ibid., p. 85 .

73. Ankersmit (2012, p. 98).

74. Ibid., p. 56.

75. Voss $(2006$, p. 81$)$.

76. Ibid., p. 82 .

77. Hermann Kappelhoff and Sarah Greifenstein, "Metaphorische Interaktion und empathische Verkörperung: Thesen zum filmischen Erfahrungsmodus," in Malte Hagener and Íngrid Vendrell Ferran (eds.), Empathie im Film: Perspektiven der Ästhetischen Theorie, Phänomenologie und Analytischen Philosophie, Bielefeld 2017, pp. 172-173.

78. Ibid.

79. Sobchack uses this phrase, coined by Merleau-Ponty, as a definition of film. See Sobchack (1992, p. 3).

80. Here, I am still following Kappelhoff and Greifenstein, who understand the process of empathy as a metaphorical interaction that "relates the experiences lived in our own bodies to modes of experience from other subject positions [than that of the film's gaze]." Kappelhoff and Greifenstein (2017, p. 177).

81. "An experiential field in which human beings pretheoretically construct and play out a particular-and culturally encoded-form of temporal existence." This quotation comes from Sobchack's reflections on historical epics, which can also be extended to historical films in general. Vivian Sobchack: "'Surge and Splendor': A Phenomenology of the Hollywood Historical Epic," in Barry Keith Grant (ed.), Film Genre Reader III, Austin 2007, p. 300.

82. Balázs (1998, p. 220).

83. Imaginative empathy is also referred to as "central imagining." The term "acentral imagining," by contrast, signifies that "the spectator need not imagine what is happening on the screen from any specific point of view 
in the fiction"; their reactions can be merely sympathetic or antipathetic. See Margrethe Bruun Vaage, "Empathy and the Episodic Structure of Engagement in Fiction Film," in Joseph D. Anderson and Barbara Fisher Anderson, (eds.), Narration and Spectatorship in Moving Images, Cambridge 2007, p. 187.

84. Ibid., p. 188.

85. Ibid., p. 189.

86. On this point, Vaage remarks: "As sense impression may or may not attract attention to itself, so perhaps may central imagining." Ibid.

87. Ibid, pp. 187, 189.

88. Amy Coplan, "Understanding Empathy: Its Features and Effects," in Amy Coplan and Peter Goldie (eds.), Empathy: Philosophical and Psychological Perspectives, Oxford 2011, p. 17.

89. Balázs (1998, p. 220).

90. Jens Eder, "Imaginative Nähe zu Figuren," montage $A V$ 15:2, 2006, p. 138.

91. Though this is not to deny that makers of propaganda films have frequently attempted to do just that.

92. Hagener and Vendrell Ferran $(2017$, p. 22$)$.

93. Vaage $(2007$, p. 198).

94. Ibid., p. 197.

95. See Hans J. Wulff, "Empathie als Dimension des Filmverstehens: Ein Thesenpapier," montage AV 12:1, 2003, p. 140.

96. Ibid., p. 143.

97. Ibid.

98. Ibid., p. 142.

99. Vaage concludes from this that "empathy may contribute both to engagement in the fiction [...], to aesthetic experience and appreciation, and sometimes even to self-reflection about the spectator's real self." Vaage (2007, p. 187).

100. $\operatorname{Wulff}(2003$, p. 138).

101. Ibid., p. 151.

102. Ibid., p. 157.

103. See Knut Hickethier, "Zeitgeschichte in der Mediengesellschaft: Dimensionen und Forschungsperspektiven," Zeithistorische Forschungen 6, 2009 , p. 364.

104. Susanne Schmetkamp, "Perspektive und empathische Resonanz: Vergegenwärtigung anderer Sichtweisen," in Hagener and Vendrell Ferran $(2017$, p. 136).

105. Kracauer (1997, p. 158).

106. See the discussion of "mirror neurons" in Hartmut Rosa, Resonanz: Eine Soziologie der Weltbeziehung, Berlin 2016, p. 251. 
107. Ibid.

108. Hermann Kappelhoff, Kognition und Reflexion: Zur Theorie filmischen Denkens, Berlin 2018, pp. 50-51.

109. Ibid.

110. Ibid., pp. 266-267.

111. Coplan stresses the role of narrativity, whereby we do not directly adopt a felt mood but instead empathetically take a perspective that allows a separation of self and other. See Coplan and Goldie (2011, pp. 3-18).

112. See Schmetkamp $(2017$, p. 137). The connection between moods and empathetic engagement again echoes Balázs's concept of an "anthropomorphous world," in which "every shape makes a-mostly unconsciousemotional impression on us, which may be pleasant or unpleasant, alarming or reassuring, because it reminds us, however distantly, of some human face." Balázs $(2015$, p. 92$)$.

113. See Schmetkamp (2017, p. 141).

114. Ibid., p. 156.

115. As well as the parallels that Kracauer draws attention to in his History, the mirror metaphor he adapts from Benjamin is also worthy of note. See Kracauer (1997, p. 305); Siegfried Kracauer, History - the Last Things Before the Last, Princeton 1995. On this topic, see also the section "Film experience and history" in the chapter "Film/history/experience."

116. Schmetkamp (2017, p. 159).

117. Vaage (2007, p. 195).

118. Sobchack $(2007$, p. 300$)$.

119. Vaage $(2007$, p. 196).

120. Ankersmit (2012, p. 19).

121. Voss (2006, p. 81).

122. Ibid., p. 82.

123. Schmetkamp (2017, p. 137).

124. Sobchack $(2007$, p. 300).

\section{BIBLIOGRAPHY}

Frank R. Ankersmit, Die historische Erfahrung, Berlin 2012.

Mikhail Bakhtin, "Forms of Time and of the Chronotope in the Novel," in his The Dialogic Imagination: Four Essays, Austin 1981.

Béla Balázs, Theory of the Film: Character and Growth of a New Art, Scotts Valley 2015.

Béla Balázs, Early Film Theory, New York and Oxford 2010.

Béla Balázs, "Zur Kunstphilosophie des Films," in Franz-Josef Albersmeier (ed.), Texte zur Theorie des Films, Stuttgart 1998, pp. 201-223.

Philipp Brunner, Jörg Schweinitz, and Margrit Tröhler (eds.), Filmische Atmosphären, Marburg 2012. 
Margrethe Bruun Vaage, "Empathy and the Episodic Structure of Engagement in Fiction Film," in Joseph D. Anderson and Barbara Fisher Anderson, (eds.), Narration and Spectatorship in Moving Images, Cambridge 2007, pp. 101-120.

Michel Chion, Audio-Vision: Sound on Screen, New York 2019.

Amy Coplan and Peter Goldie (eds.), Empathy: Philosophical and Psychological Perspectives, Oxford 2011.

Robin Curtis, "Immersion und Einfühlung: Zwischen Repräsentationalität und Materialität bewegter Bilder," montage AV 17:2, 2008, pp. 89-107.

Robin Curtis and Christiane Voss, "Fielding und die movie-ride-Ästhetik: Vom Realismus zur Kinesis," montage AV 17:2, 2008, pp. 11-15.

Jens Eder, "Imaginative Nähe zu Figuren," montage AV 15:2, 2006, pp. 135-160.

Barbara Flückiger, Sound Design: Die virtuelle Klangwelt des Films, Marburg 2012.

Urban Gad, Der Film: Seine Mittel, seine Ziele, Berlin 1920.

Robert Gugutzer, "Hermann Schmitz: Der Gefühlsraum," in Konstanze Senge (ed.), Hauptwerke der Emotionssoziologie, Wiesbaden 2013, pp. 304-310.

Malte Hagener and Íngrid Vendrell Ferran (eds.), Empathie im Film: Perspektiven der Ästhetischen Theorie, Phänomenologie und Analytischen Philosophie, Bielefeld 2017.

Matthias Hein, Zu einer Theorie des Erlebens bei Béla Balázs, Würzburg 2011.

Knut Hickethier, "Zeitgeschichte in der Mediengesellschaft: Dimensionen und Forschungsperspektiven," Zeithistorische Forschungen 6, 2009, pp. 347-366.

Hermann Kappelhoff, Kognition und Reflexion: Zur Theorie filmischen Denkens, Berlin 2018.

Hermann Kappelhoff and Jan-Hendrik Bakels, "Das Zuschauergefühl Möglichkeiten qualitativer Medienanalyse," ZfM 5, 2011, pp. 78-95.

Hermann Kappelhoff and Sarah Greifenstein, "Metaphorische Interaktion und empathische Verkörperung: Thesen zum filmischen Erfahrungsmodus," in Hagener and Vendrell Ferran 2017, pp. 167-194.

Gertrud Koch, Die Wiederkehr der Illusion: Der Film und die Kunst der Gegenwart, Berlin 2016.

Siegfried Kracauer, History — the Last Things Before the Last, Princeton 1995.

Siegfried Kracauer, Theory of Film: The Redemption of Physical Reality, Princeton 1997.

Alison Landsberg, Prosthetic Memory: The Transformation of American Remembrance in the Age of Mass Culture, New York 2004.

Theodor Lipps, Leitfaden der Psychologie, Leipzig 1906.

Christian Metz, The Imaginary Signifier: Psychoanalysis and the Cinema, Bloomington and Indianapolis 1982.

Paul Ricour, Time and Narrative, vol. 1, Chicago and London 1984.

Hartmut Rosa, Resonanz: Eine Soziologie der Weltbeziehung, Berlin 2016.

Marie-Laure Ryan, Narrative as Virtual Reality: Immersion and Interactivity in Literature and Electronic Media, Baltimore and London 2001.

Susanne Schmetkamp, "Perspektive und empathische Resonanz: Vergegenwärtigung anderer Sichtweisen," in Hagener and Vendrell Ferran 2017, pp. 133-166. 
Oliver Schmidt, Hybride Räume: Filmwelten im Hollywood-Kino der Jahrtausendwende, Marburg 2013.

Hermann Schmitz, Der Leib, der Raum und die Gefüble, Bielefeld and Locarno 2007.

Hermann Schmitz, “Über das Machen von Atmosphären,” in Anna Blume, Zur Phänomenologie der ästhetischen Erfahrung, Freiburg and Munich 2005, pp. 26-43.

Hermann Schmitz, "Gefühle als Atmosphären und das affektive Betroffensein von ihnen," in Hinrich Fink-Eitel and Georg Lohmann (eds.), Zur Philosophie der Gefüble, Frankfurt 1993, pp. 33-56.

Jörg Schweinitz, "Von Transparenz und Intransparenz: Über die Atmosphäre historischen Filmmaterials," in Brunner, Schweinitz, and Tröhler 2012, pp. 39-52.

Martin Seel, Aesthetics of Appearing, Stanford 2005.

Greg M. Smith, Film Structure and the Emotion System, Cambridge 2007.

Vivian Sobchack, "'Surge and Splendor': A Phenomenology of the Hollywood Historical Epic," in Barry Keith Grant (ed.), Film Genre Reader III, Austin 2007, 296-323.

Vivian Sobchack, Carnal Thoughts: Embodiment and Moving Image Culture, Berkeley 2004.

Vivian Sobchack, The Address of the Eye: A Phenomenology of Film Experience, Princeton 1992.

Margrit Tröhler, "Filmische Atmosphären - Eine Annäherung," in Philipp Brunner, Jörg Schweinitz, and Margrit Tröhler (eds.), Filmische Atmosphären, Marburg 2012, pp. 11-24.

Christiane Voss, Der Leibkörper: Erkenntnis und Ästhetik der Illusion, Paderborn 2013.

Christiane Voss, "Fiktionale Immersion," in Gertrud Koch and Christiane Voss, "Es ist, als ob": Fiktionalität in Philosophie, Film- und Medienwissenschaft, Munich 2009, pp. 127-137.

Christiane Voss, "Fiktionale Immersion," montage AV 17:2, 2008, pp. 69-86.

Christiane Voss, "Filmerfahrung und Illusionsbildung: Der Zuschauer als Leihkörper des Films," in Gertrud Koch and Christiane Voss (eds.), ...kraft der Illusion, Munich 2006, pp. 71-86.

Daniel Wiegand, “'Die Wahrheit aber ist es nicht allein': Zur Idee der Stimmung im Film nach 1910," in Brunner, Schweinitz, and Tröhler 2012, pp. 193-210.

Hans J. Wulff, "Prologema zu einer Theorie des Atmosphärischen im Film," in Brunner, Schweinitz, and Tröhler 2012, pp. 136-161.

Hans J. Wulff, "Empathie als Dimension des Filmverstehens: Ein Thesenpapier," montage AV 12:1, 2003, pp. 136-161.

Anke Zechner, Die Sinne im Kino: Eine Theorie der Filmwahrnehmung, Frankfurt 2013. 
Filmography

Atmosphäre. Untersuchungen zu einem Begriff; dir. Elisabeth Blum; Switzerland 2010.

Ku'damm 56; dir. Sven Bohse; Germany 2016.

Sky without Stars (Himmel ohne Sterne); dir. Helmut Käutner; Federal Republic of Germany 1955.

Years of Hunger (Hungerjahre); dir. Jutta Brückner; Federal Republic of Germany 1980.

Open Access This chapter is licensed under the terms of the Creative Commons Attribution 4.0 International License (http://creativecommons.org/licenses/ by $/ 4.0 /)$, which permits use, sharing, adaptation, distribution and reproduction in any medium or format, as long as you give appropriate credit to the original author(s) and the source, provide a link to the Creative Commons licence and indicate if changes were made.

The images or other third party material in this chapter are included in the chapter's Creative Commons licence, unless indicated otherwise in a credit line to the material. If material is not included in the chapter's Creative Commons licence and your intended use is not permitted by statutory regulation or exceeds the permitted use, you will need to obtain permission directly from the copyright holder.

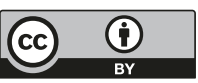

